\title{
Substituents Effect on Aziridine Chemistry: $N$-Inversion Energy, Reactivity and Regioselectivity of Nucleophilic Ring-opening
}

\author{
Gyoosoon Park, ${ }^{*}$ Seok-Chan Kim, and Han-Young Kang ${ }^{\dagger}$ \\ Department of Chemistry, Kookmin University, Seoul 136-702, Korea. *E-mail: gpark@kookmin.ac.kr \\ ${ }^{\dagger}$ Department of Chemistry, Chungbuk National University, Cheongju, Chungbuk 361-763, Korea \\ Received February 4, 2005
}

\begin{abstract}
The $N$-inversion energies and nucleophilic ring-opening reactions of $N$-substituted aziridine compounds are investigated using B3LYP/6-31+G* methods, where substituents $(\mathrm{R})$ on the nitrogen atom has been $\mathrm{H}(\mathbf{1})$, Me (2), $\mathrm{Ph}$ (3), $\mathrm{Bn}$ (4), $\mathrm{CHMePh}(5), \mathrm{CO}_{2} \mathrm{Me}(6), \mathrm{COPh}$ (7) and $\mathrm{SO}_{2} \mathrm{Ph}(8)$. The $N$-inversion energy with $\mathrm{X}$ group are decreased as the following order: $\mathrm{R}=\mathrm{CHMePh}(17.06 \mathrm{kcal} / \mathrm{mol})>\mathrm{Me}(16.97)>\mathrm{Bn}(16.70)>\mathrm{H}(16.64)>$ $\mathrm{SO}_{2} \mathrm{Ph}(12.18)>\mathrm{Ph}(8.91)>\mathrm{COPh}(5.75)>\mathrm{CO}_{2} \mathrm{Me}$ (5.48). For reactivity of the ring opening toward cyanide ion, the aziridine $6\left(\mathrm{R}=\mathrm{CO}_{2} \mathrm{Me}\right)$ is shown to be the most reactive one. During the ring opening of aziridine 6 by $\mathrm{CN}^{\ominus}$, the torsional OCNC angle becomes near to $180^{\circ}$, where the geometry allows for the effective incorporation of electrons of the nitrogen atom to the $\mathrm{C}=\mathrm{O}$ bond. It would be a possible driving force for nucleophilic ring opening reaction as well as decreasing the $N$-inversion energy barrier. Regarding to the regioselectivity, the orientation of nucleophile in ring opening reaction appears to be different in the case of 9 and 10. The results are discussed in terms of steric/electronic effect of the $\mathrm{C}_{2}$-substituents.
\end{abstract}

Key Words : Aziridine, $N$-Inversion energy, Nucleophilic ring-opening, Ab initio

\section{Introduction}

Aziridine functionality represents a valuable three-membered ring system in modern synthetic chemistry. It is well recognized as a significant building block for synthesizing many useful compounds. The nucleophilic ring-opening of the aziridine derivatives has been an important transformation to prepare numerous organic compounds. ${ }^{1-3}$ Although the ring-opening of aziridines by nucleophiles is relatively facile due to the strain of three-membered ring, strong nucleophiles or acid catalysts are required in the case of nonactivated group (e.g., $\mathrm{H}$, alkyl, or aryl) on the nitrogen atom in the aziridine ring. Thus, it becomes imperative to introduce $N$-substituents (e.g., $\mathrm{COR}, \mathrm{CO}_{2} \mathrm{R}$, or $\mathrm{SO}_{2} \mathrm{R}$ ), which can stabilize the negative charge on the nitrogen atom and increase the reactivity of aziridine rings towards nucleophiles.

The focus of the present work is to calculate optimized geometries of aziridine derivatives and to predict the

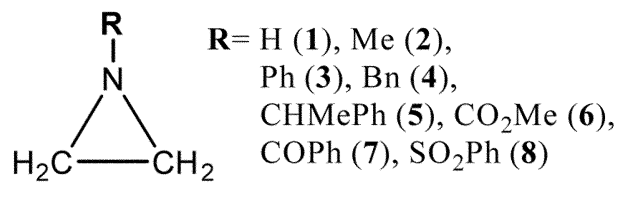

1 $\sim 8$<smiles>COC(=O)N1CC1C</smiles>

9<smiles>CC(=O)C1CN1C(C)=O</smiles>

10 possible $N$-inversion energy barriers from planar-shaped transition states using B3LYP/6-31+G* methods. ${ }^{4} \mathrm{~N}$ Substituents in aziridines considered are $-\mathrm{H},-\mathrm{Me},-\mathrm{Ph},-\mathrm{Bn}$, $-\mathrm{CHMePh},-\mathrm{CO}_{2} \mathrm{Me},-\mathrm{COPh}$, and $-\mathrm{SO}_{2} \mathrm{Ph}$. We have also investigated the transition states of nucleophilic ringopening reactions by cyanide anion. Here we wish to clarify; i) the effect of $N$-substituents on aziridine ring geometries and ii) their $N$-inversion energy barriers, iii) the influence of nucleophilic ring-opening reactions depending upon $\mathrm{N}$ substituents, and iv) possible selectivity on ring-opening by nucleophiles.

Computational methods. $A b$ initio calculations and geometry optimizations were carried out for all the above mentioned aziridine compounds with the gaussian-98 program package ${ }^{5}$ using the standard $6-31+\mathrm{G}^{*}$ basis set with density functional (B3LYP) methods. ${ }^{6}$ For the planar-shaped transition state structure, only one imaginary frequency value was obtained. Also in the transition state structures ${ }^{7}$ of nucleophilic ring opening reactions of aziridines, one imaginary frequency value was accepted.

\section{Results and Discussion}

The equilibrium states and $N$-inversion energies of aziridines. Using density functional method B3LYP/6$31+\mathrm{G}^{*}$, it has been determined the structural geometrical parameters of the equilibrium state and planar-shaped transition states of aziridines 1-8. The results are summarized in Table 1. For the planar-shaped transition states, it is confirmed that the motion at the imaginary frequencies correspond to the $N$-inversion. In quasi-pyramidal aziridines, the total bond angles around the nitrogen atom vary with $\mathrm{N}$ substituents (R). The order of relative flatness (i.e., $360.0^{\circ}$ 
Table 1. The optimized equilibrium states and planar-shaped transition states of aziridines $\mathbf{1 - \mathbf { 8 } ^ { a }}$

\begin{tabular}{|c|c|c|c|c|c|c|c|c|c|c|}
\hline & $\mathbf{R}$ & $\mathrm{E}_{\mathrm{tot}}^{b}$ & $\mathrm{~N}_{1}-\mathrm{R}^{c}$ & $\mathrm{~N}_{1}-\mathrm{C}_{2}^{c}$ & $\mathrm{~N}_{1}-\mathrm{C}_{3}^{c}$ & $\mathrm{R}-\mathrm{N}_{1}-\mathrm{C}_{2}{ }^{d}$ & $\mathrm{R}-\mathrm{N}_{1}-\mathrm{C}_{3}{ }^{d}$ & $\mathrm{C}_{2}-\mathrm{N}_{1}-\mathrm{C}_{3}{ }^{d}$ & $\mathrm{C}_{2}-\mathrm{N}_{1}-\mathrm{X}-\mathrm{O}^{e}$ & $\mathrm{E}_{\mathrm{inv}}{ }^{f}$ \\
\hline 1 & $\mathrm{H}$ & $\begin{array}{c}-133.9265337 \\
(-133.9000049)\end{array}$ & $\begin{array}{c}1.019 \\
(1.002)\end{array}$ & $\begin{array}{c}1.474 \\
(1.406)\end{array}$ & $\begin{array}{c}1.474 \\
(1.406)\end{array}$ & $\begin{array}{c}110.750 \\
(146.937)\end{array}$ & $\begin{array}{c}110.750 \\
(147.012)\end{array}$ & $\begin{array}{c}60.623 \\
(66.051)\end{array}$ & - & 16.647 \\
\hline 2 & $\mathrm{Me}$ & $\begin{array}{c}-173.2385754 \\
(-173.2115217)\end{array}$ & $\begin{array}{c}1.459 \\
(1.427)\end{array}$ & $\begin{array}{c}1.462 \\
(1.402)\end{array}$ & $\begin{array}{c}1.462 \\
(1.402)\end{array}$ & $\begin{array}{c}116.153 \\
(146.794)\end{array}$ & $\begin{array}{c}116.145 \\
(146.862)\end{array}$ & $\begin{array}{c}61.453 \\
(66.343)\end{array}$ & - & 16.976 \\
\hline 3 & $\mathrm{Ph}$ & $\begin{array}{c}-364.9881875 \\
(-364.9739807)\end{array}$ & $\begin{array}{c}1.412 \\
(1.368)\end{array}$ & $\begin{array}{c}1.457 \\
(1.408)\end{array}$ & $\begin{array}{c}1.457 \\
(1.408)\end{array}$ & $\begin{array}{c}121.234 \\
(147.025)\end{array}$ & $\begin{array}{c}121.232 \\
(147.061)\end{array}$ & $\begin{array}{c}61.823 \\
(65.914)\end{array}$ & - & 8.915 \\
\hline 4 & $\mathrm{Bn}$ & $\begin{array}{c}-404.2983206 \\
(-404.2716955)\end{array}$ & $\begin{array}{c}1.465 \\
(1.428)\end{array}$ & $\begin{array}{c}1.462 \\
(1.404)\end{array}$ & $\begin{array}{c}1.461 \\
(1.405)\end{array}$ & $\begin{array}{c}116.108 \\
(147.831)\end{array}$ & $\begin{array}{c}116.358 \\
(145.950)\end{array}$ & $\begin{array}{c}61.451 \\
(66.218)\end{array}$ & - & 16.707 \\
\hline 5 & $\mathrm{CHMePh}$ & $\begin{array}{c}-443.6158852 \\
(-443.5886913)\end{array}$ & $\begin{array}{l}1.470 \\
(1.436)\end{array}$ & $\begin{array}{c}1.461 \\
(1.406)\end{array}$ & $\begin{array}{c}1.461 \\
(1.404)\end{array}$ & $\begin{array}{c}116.576 \\
(147.988)\end{array}$ & $\begin{array}{c}116.341 \\
(145.850)\end{array}$ & $\begin{array}{c}61.427 \\
(66.162)\end{array}$ & - & 17.064 \\
\hline 6 & $\mathrm{CO}_{2} \mathrm{Me}$ & $\begin{array}{c}-361.8180163 \\
(-361.8092781)\end{array}$ & $\begin{array}{c}1.388 \\
(1.350)\end{array}$ & $\begin{array}{l}1.456 \\
(1.413)\end{array}$ & $\begin{array}{c}1.449 \\
(1.417)\end{array}$ & $\begin{array}{c}122.222 \\
(145.201)\end{array}$ & $\begin{array}{c}124.379 \\
(149.323)\end{array}$ & $\begin{array}{c}62.308 \\
(65.476)\end{array}$ & $\begin{array}{l}46.106 \\
(0.000)\end{array}$ & 5.483 \\
\hline 7 & $\mathrm{COPh}$ & $\begin{array}{c}-478.3364984 \\
(-478.3273281)\end{array}$ & $\begin{array}{c}1.402 \\
(1.362)\end{array}$ & $\begin{array}{l}1.448 \\
(1.416)\end{array}$ & $\begin{array}{c}1.463 \\
(1.423)\end{array}$ & $\begin{array}{c}123.659 \\
(140.814)\end{array}$ & $\begin{array}{c}121.077 \\
(154.265)\end{array}$ & $\begin{array}{c}62.029 \\
(64.921)\end{array}$ & $\begin{array}{l}32.510 \\
(0.054)\end{array}$ & 5.754 \\
\hline 8 & $\mathrm{SO}_{2} \mathrm{Ph}$ & $\begin{array}{c}-913.5670528 \\
(-913.5476283)\end{array}$ & $\begin{array}{c}1.723 \\
(1.641)\end{array}$ & $\begin{array}{l}1.478 \\
(1.421)\end{array}$ & $\begin{array}{c}1.477 \\
(1.421)\end{array}$ & $\begin{array}{c}117.731 \\
(147.568)\end{array}$ & $\begin{array}{c}115.539 \\
(147.012)\end{array}$ & $\begin{array}{c}60.421 \\
(65.076)\end{array}$ & $\begin{array}{c}17.494,80.786 \\
(22.256,25.517)\end{array}$ & 12.189 \\
\hline
\end{tabular}

${ }^{a}$ The values in parenthesis are for the planar-shaped transition states. ${ }^{b}$ Total energy (hartree). ${ }^{c}$ Bond lengths (angstrom, $\AA$ ). ${ }^{d}$ Bond angle (degree, ${ }^{\circ}$ ). ${ }^{e}$ Torsion angle (degree, ${ }^{\circ}$ ). $\mathrm{C}_{2}-\mathrm{N}_{1}-\mathrm{C}=\mathrm{O}$ for $\mathbf{6}$ and $7, \mathrm{C}_{2}-\mathrm{N}_{1}-\mathrm{S}=\mathrm{O}$ for $8 .{ }^{f} \mathrm{~N}$-Inversion energy (kcal/mol), which are calculated from $\mathrm{E}_{\text {tot }}$ of the equilibrium states and planar-shaped transition states.

for complete planar geometry) with $\mathrm{R}$ group is shown by $\mathrm{CO}_{2} \mathrm{Me}\left(308.9^{\circ}\right)>\mathrm{COPh}\left(306.8^{\circ}\right)>\mathrm{Ph}\left(304.3^{\circ}\right)>\mathrm{CHMePh}$ $\left(294.3^{\circ}\right)>\mathrm{Bn}\left(293.9^{\circ}\right)>\mathrm{Me}\left(293.8^{\circ}\right)>\mathrm{SO}_{2} \mathrm{Ph}\left(293.7^{\circ}\right)>\mathrm{H}$ $\left(282.1^{\circ}\right)$. Consequently aziridine $6\left(\mathrm{R}=\mathrm{CO}_{2} \mathrm{Me}\right)$ appears mostly near to planar ring geometry.

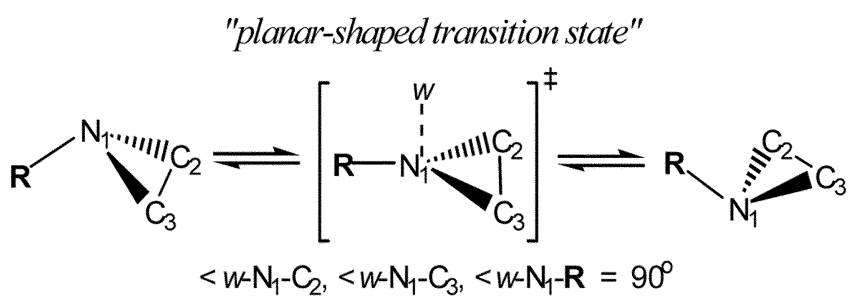

It shows further that, in the planar-shaped transition state, the increase in all bond angle values are accompanied by a decrease in bond lengths in general. In the case of $\mathbf{6}$, for example, the $\mathrm{N}-\mathrm{R}$ bond length changes from $1.388 \AA$ to $1.350 \AA$, and the $\mathrm{C}_{2}-\mathrm{N}_{1}-\mathrm{C}_{3}$ strained angle increases from $62.308^{\circ}$ to $65.476^{\circ}$. It is noted that the variations of the strained angle $\left(\angle \mathrm{C}_{2}-\mathrm{N}_{1}-\mathrm{C}_{3}\right)$ are relatively small when nitrogen atom is directly substituted with a $\mathrm{sp}^{2}$-carbon compare to the case of being substituted with a $\mathrm{sp}^{3}$-carbon. For examples, the angle variations are $2.89^{\circ}$ for 7 $(\mathrm{R}=\mathrm{COPh}), 3.17^{\circ}$ for $\mathbf{6}\left(\mathrm{R}=\mathrm{CO}_{2} \mathrm{Me}\right)$, and $4.74^{\circ}$ for $\mathbf{5}$ $(\mathrm{R}=\mathrm{CHMePh})$. In 6 and 7 , the $\mathrm{C}=\mathrm{O}$ bonds and aziridine rings lie in same plane (torsion angles of $\mathrm{C}_{2}-\mathrm{N}_{1}-\mathrm{C}_{4}=\mathrm{O}$ are zero), which apparently the non-bonding electrons on the nitrogen are completely incorporated to the $\pi$-electrons of the $\mathrm{C}=\mathrm{O}$ bonds by maintaining coplanarity with the ring. For $8\left(\mathrm{R}=\mathrm{SO}_{2} \mathrm{Ph}\right)$, the electrons on the nitrogen may not be able to exhibit complete incorporation (the torsion angle of $\mathrm{C}_{2}$ $\mathrm{N}_{1}-\mathrm{S}=\mathrm{O}$ are $22.25^{\circ}, 25.51^{\circ}$ ). According to the above results, $\mathrm{C}=\mathrm{O}$ functionality in $\mathrm{R}$ group effectively accomodate aziridine ring towards coplanarity than other substituents such as $\mathrm{S}(=\mathrm{O})_{2}$ group.

It has been known the energy barrier of $N$-inversion of non-cyclic trivalent amines is $6-7 \mathrm{kcal} / \mathrm{mol}$ at room temperature, ${ }^{8}$ and the strain of three-membered aziridine ring geometry causes the $\mathrm{N}$-inversion energy to increase. $\mathrm{N}$ Inversion energies of aziridines are calculated to be more than $16 \mathrm{kcal} / \mathrm{mol}(16.6-17.1 \mathrm{kcal} / \mathrm{mol}$ for $\mathbf{1}, \mathbf{2}, \mathbf{4}$, and 5 in Table 1), which consistent with the literature values, ${ }^{8 \mathrm{~b}}$ in the case that the steric effect of $\mathrm{N}$-substituent does not seem significant. However, those values in $6\left(\mathrm{R}=\mathrm{CO}_{2} \mathrm{Me}\right)$ and 7 $(\mathrm{R}=\mathrm{COPh})$ are predicted to have 5.48 and $5.75 \mathrm{kcal} / \mathrm{mol}$, which are even lower than those of non-cyclic trivalent amines. With a similar argument, $N$-substituent of carbonyl $(\mathrm{C}=\mathrm{O})$ group can decrease this energy barrier by a complete incorporation of the electrons on the $N$ of ring into planarshaped transition states. The order of $N$-inversion energy with $\mathrm{R}$ groups is predicted by $\mathrm{CHMePh}(17.06)>\mathrm{Me}$ $(16.97)>\mathrm{Bn}(16.70)>\mathrm{H}(16.64)>\mathrm{SO}_{2} \mathrm{Ph}(12.18)>\mathrm{Ph}$ $(8.91)>\mathrm{COPh}(5.75)>\mathrm{CO}_{2} \mathrm{Me}(5.48)$ as shown in Table 2 . Our results suggest that the energy barrier is decreased to about $5 \mathrm{kcal} / \mathrm{mol}$ by $N$-substituted carbonyl $(\mathrm{C}=\mathrm{O})$ group via complete incorporation of the electrons on aziridine ring- $N$. Compared with the alkyl group, the $N$-substituted carbonyl $(\mathrm{C}=\mathrm{O})$ group of aziridine ring may not allow us to isolate the resultant optically active chiral aziridine compounds. Note that $N$-substituent of an electronegative atom (e.g., a halogen or an alkoxy group) increases this energy barrier. According to our calculation using B3LYP/6-31+G*, the $N$-inversion energy of $N$-chloroaziridine is predicted by $25.1 \mathrm{kcal} / \mathrm{mol}$. The inversion energy of $24.4 \mathrm{kcal} / \mathrm{mol}$ was reported in $N$ chloro-2,2-diphenylaziridine, ${ }^{9}$ which may validate our calculation.

Nucleophilic ring opening of aziridine with the cyanide anion..$^{10,11}$ The transition states of nucleophilic ring-opening by the cyanide ion have been optimized, and the results are 


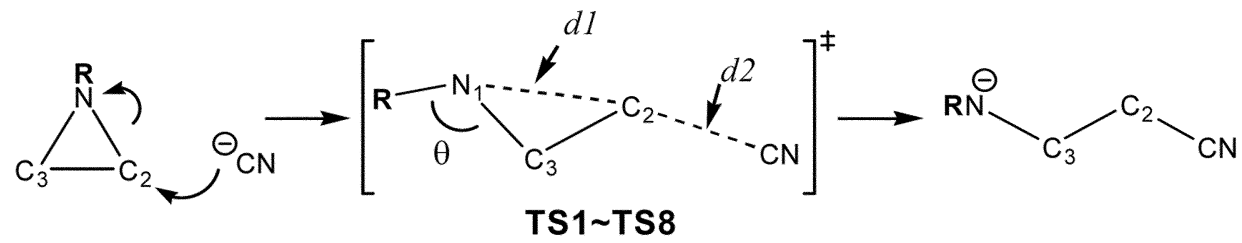

Table 2. The optimized transition state of nucleophilic ring-opening by $\mathrm{CN}^{\ominus}$

\begin{tabular}{|c|c|c|c|c|c|c|c|c|c|}
\hline & $\mathbf{R}$ & $\mathrm{ETS}^{a}$ & $\mathrm{~N}_{1}-\mathrm{R}^{b}$ & $\mathrm{~N}_{1}-\mathrm{C}_{3}{ }^{b}$ & $\mathrm{~N}_{1} \cdots \mathrm{C}_{2}^{b}(d l)$ & $\mathrm{C}_{2} \cdots \mathrm{CN}^{b}(d 2)$ & $\mathrm{C}_{3}-\mathrm{N}_{1}-\mathrm{R}^{c}(\theta)$ & $\mathrm{C}_{3}-\mathrm{N}_{1}-\mathrm{X}=\mathrm{O}^{d}$ & $\Delta \mathrm{E}^{d}\left(\mathrm{E}_{\mathrm{a}}\right)$ \\
\hline TS-1 & $\mathrm{H}$ & -226.7604567 & 1.028 & 1.452 & 2.019 & 2.166 & 106.633 & - & $\begin{array}{c}19.770 \\
(30.843)\end{array}$ \\
\hline TS-2 & $\mathrm{Me}$ & -266.0699095 & 1.447 & 1.452 & 1.986 & 2.150 & 111.691 & - & $\begin{array}{c}21.395 \\
(15.292)\end{array}$ \\
\hline TS-3 & $\mathrm{Ph}$ & -457.8400841 & 1.382 & 1.444 & 1.862 & 2.320 & 119.698 & - & $\begin{array}{c}8.492 \\
(7.354)\end{array}$ \\
\hline TS-4 & $\mathrm{Bn}$ & -497.1357149 & 1.443 & 1.451 & 1.957 & 2.181 & 112.540 & - & $\begin{array}{c}17.592 \\
(12.565)\end{array}$ \\
\hline TS-5 & $\mathrm{CHMePh}$ & -536.4534739 & 1.447 & 1.451 & 1.956 & 2.185 & 112.831 & - & $\begin{array}{l}17.470 \\
(8.208)\end{array}$ \\
\hline TS-6 & $\mathrm{CO}_{2} \mathrm{Me}$ & -454.6769873 & 1.358 & 1.447 & 1.810 & 2.371 & 120.088 & 163.021 & $\begin{array}{c}4.053 \\
(5.080)\end{array}$ \\
\hline TS-7 & $\mathrm{COPh}$ & -571.1914058 & 1.358 & 1.459 & 1.813 & 2.298 & 123.086 & 141.543 & $\begin{array}{c}6.602 \\
(7.793)\end{array}$ \\
\hline TS-8 & $\mathrm{SO}_{2} \mathrm{Ph}$ & -1006.435897 & 1.652 & 1.450 & 1.788 & 2.418 & 116.748 & $160.969 \& 27.130$ & $\begin{array}{l}-2.143 \\
(9.057)\end{array}$ \\
\hline
\end{tabular}

${ }^{a}$ Total energy of transition state (hartree). ${ }^{b}$ Bond lengths (angstrom, $\AA$ ). ${ }^{c}$ Bond angle $\theta$ (degree, ${ }^{\circ}$ ). ${ }^{d}$ Torsion angle (degree, ${ }^{\circ}$ ). $\mathrm{C}_{3}-\mathrm{N}_{1}-\mathrm{C}=\mathrm{O}$ for TS-6 and TS-7, $\mathrm{C}_{3}-\mathrm{N}_{1}-\mathrm{S}=\mathrm{O}$ for TS-8. ${ }^{e} \Delta \mathrm{E}(\mathrm{kcal} / \mathrm{mol})$ is obtained from the total energy of aziridine (in table 1$)$ and $\mathrm{CN}$ to the transition state energy ETS, where $\mathrm{CN}$-energy is -92.865429287 . The values in parenthesis are obtained from the initial complex energies of aziridine and $\mathrm{CN}$, which are denoted by ' $\mathrm{E}_{\mathrm{a}}$ ' $\mathrm{s}$. The initial complex energies of $\mathbf{1 - 8}$ are $-226.8096082,-266.0942799,-457.8518035,-497.1557388,-536.4665538,-454.6850826,-571.2038246$, -1006.450331 , respectively.

summarized in Table 2. It shows that the distances of $\mathrm{N}_{1} \cdots \mathrm{C}_{2}(d 1)$ and $\mathrm{C}_{2} \cdots \mathrm{CN}(d 2)(\mathrm{R}=\mathrm{H})$ appear at $2.019 \AA$ and $2.166 \AA$ in TS-1, respectively. Also the corressponding values for TS-4 $(\mathrm{R}=\mathrm{Bn})$ are $1.957 \AA$ and $2.182 \AA$, respectively, where $d 1$ is decreased and $d 2$ is increased. In the case of TS-6 $\left(\mathrm{R}=\mathrm{CO}_{2} \mathrm{Me}\right)$, the structure becomes more

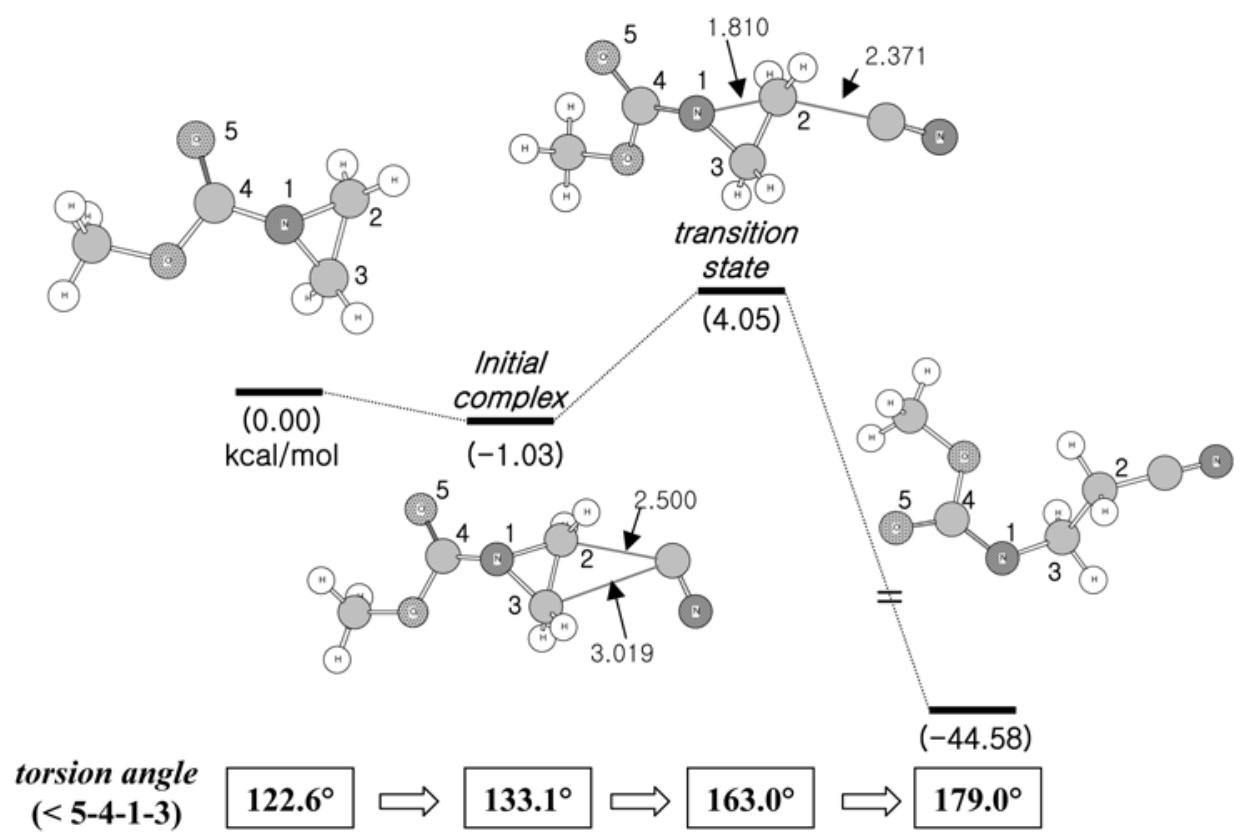

Figure 1. Reaction profile of nucleophilic ring-opening of aziridine 6. 

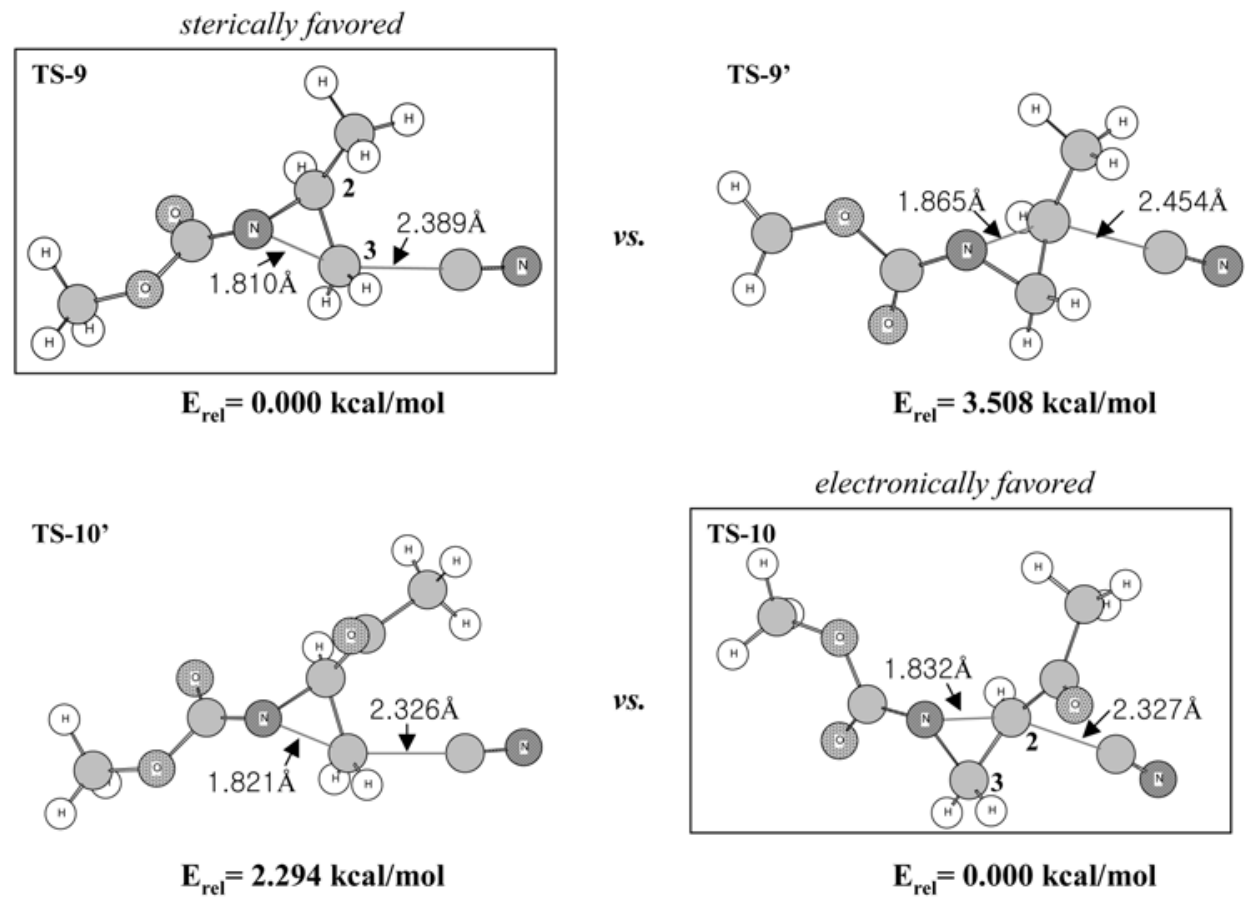

Figure 2. The structures and relative energies of TS-9 and TS-10.

similar (i.e., $d 1=1.810 \AA$ and $d 2=2.371 \AA$ ) to that of the starting point of the reaction. The energy variations (denoted by " $\mathrm{E}_{\mathrm{a}}$ "), between energy of the initial complex and the corresponding $\mathrm{E}_{\mathrm{TS}}$, are $30.84 \mathrm{kcal} / \mathrm{mol}$ for TS-1 and 5.08 $\mathrm{kcal} / \mathrm{mol}$ for TS-6. The order of $\mathrm{E}_{\mathrm{a}}$ (in $\mathrm{kcal} / \mathrm{mol}$ ) with $N$ substituents $\mathrm{R}$ group is predicted by $\mathrm{H}(30.84)>\mathrm{Me}(15.29)$ $>\mathrm{Bn}(12.56)>\mathrm{SO}_{2} \mathrm{Ph}(9.05)>\mathrm{CHMePh}(8.20)>\mathrm{COPh}$ (7.79) $>\mathrm{Ph}(7.35)>\mathrm{CO}_{2} \mathrm{Me}(5.08)$ as shown in Table 2. Although the $E_{a}$ values in this investigation may not represent the practical ones, the relative trend should be reliable. Thus it implies that $\mathrm{COPh}$ and $\mathrm{CO}_{2} \mathrm{Me}$ behaves as activating groups to cause facile ring opening.

Figure 1 shows reaction profile for the ring opening reaction of aziridine 6 with $\mathrm{CN}^{\ominus}$. The overall reaction appears exothermic, with the $\mathrm{E}_{\mathrm{a}}$ predicted by $5.08 \mathrm{kcal} / \mathrm{mol}$. It should be noted the torsional angles ( $\angle 5-4-1-3)$ are changed during the reaction. From the starting aziridine to the ring opening product, the torsional angle was varied by $122.6^{\circ} \rightarrow 133.1^{\circ} \rightarrow 163.0^{\circ} \rightarrow 179.0^{\circ}$. Coplanarity has become maintained between $\mathrm{C}=\mathrm{O}$ and $\mathrm{N}_{1}-\mathrm{C}_{3}$ bonds for achieving a complete incorporation of electrons on $\mathrm{N}$ and $\mathrm{C}=\mathrm{O}$ bond. Apparently, it suggests the geometrical allowance for this complete incorporation may be a possible driving force of the ring opening reaction, which accords with the trend of the $N$-inversion energy of 6 or 7 .

For the investigation of the regio-selectivities on ringopening (i.e., $\mathrm{C}_{2}$ vs. $\mathrm{C}_{3}$ ), the possible transition states, which corresponds to the reaction of $\mathrm{CN}^{\ominus}$ attack to aziridine 9 and 10, have been optimized. Figure 2 shows the structures and relative energies of TS-9 and TS-10. For the reaction of $\mathbf{9}$, $\mathrm{CN}^{\ominus}$ nucleophile prefers to attack less hindered center $\mathrm{C}_{3}$ (i.e., TS-9 energy is lower than TS-9' by $3.51 \mathrm{kcal} / \mathrm{mol}$ as shown in Figure 2) due to the steric effect of $\mathrm{C}_{2}-\mathrm{Me}$ group. In the case of TS-10, C2-attack is favored (the energy of TS10 predicted is lower than TS-10' by $2.29 \mathrm{kcal} / \mathrm{mol}$ ). It might due to a possible electron-withdrawing effect of the $\mathrm{C}_{2}$-COMe group. Similar rationale has been reported. ${ }^{3}$ This calculation method may provide an excellent example for the prediction of regioselectivity of nucleophilic ringopening of $N$-substituted aziridines.

\section{Conclusions}

The structure of the above mentioned aziridines (1-8) in equilibrium state and planar-shaped transition state were determined using DFT method (B3LYP/6-31+G*) as shown in Table 1 . The $N$-inversion energy barrier of $\mathbf{6}$ is predicted to be $5.08 \mathrm{kcal} / \mathrm{mol}$, which is even lower than non-cyclic trivalent amines. Using the same method above, the transition states of ring opening reaction with cyanide ion have been optimized, and relative activation energies are calculated as shown in Table 2. During the reaction of $\mathbf{6}$ with $\mathrm{CN}^{\ominus}$, it also has been noted that the torsion angle maintains coplanar geometry between $\mathrm{C}=\mathrm{O}$ and $\mathrm{N}_{1}-\mathrm{C}_{3}$ bond. These results can be understood by an incorporation between the electrons on the ring- $\mathrm{N}$ and the $\pi$-electrons of $\mathrm{C}=\mathrm{O}$ bond. Although those values in Table 2 are somewhat semiquantitative, they provide relative reactivity of aziridines depending on $N$-substituents and suggests that $\mathrm{E}_{\mathrm{a}}$ and $\mathrm{E}_{\text {inv }}$ are decreased with $\mathrm{C}=\mathrm{O}$ functionality on the ring-N. In addition, the transition states $\mathbf{9}$ and $\mathbf{1 0}$ have been optimized. The regio-selective ring-opening $\left(\mathrm{C}_{2}\right.$ vs. $\left.\mathrm{C}_{3}\right)$ is proven to be influenced by steric/electronic effect of $\mathrm{C}_{2}$-substituents. The regioselectivity is efficiently predicted by this calculation 
and all the results provide excellent informations for understanding of the chemical nature of aziridines.

Acknowledgement. This work was supported by the Kookmin University.

\section{References}

1. For recent reviews on nucleophilic ring opening of aziridines, see: (a) Hu, X. R. Tetrahedron 2004, 60, 2701. (b) McCoull, W.; Davis, F. A. Synthesis 2000, 1347.

2. For reviews of syntheses and reactions of aziridines see: (a) Padwa, A.; Woolhouse, A. D. In Comprehensive Heterocyclic Chemistry; Lwowski, W., Ed.; Pergamon: Oxford, 1984; Vol. 7, pp 47-93. (b) Kasai, M.; Kono, M. Synlett 1992, 778. (c) Tanner, D. Angew. Chem., Int. Ed. Engl. 1994, 33, 599. (d) Osborn, H. M. I.; Sweeney, J. Tetrahedron: Asymmetry 1997, 8, 1693.

3. For an recent report of synthetic application of aziridines see: (a) Kim, S.-W.; Noh, H.-Y.; Paek, S. I.; Ha, H.-J.; Lee, W. K. Bull. Korean Chem. Soc. 2004, 1617. (b) Yun, J. M.; Sim, T. B.; Hahm, H. S.; Lee, W. K.; Ha, H.-J. J. Org. Chem. 2003, 68, 7675. (c) Lee, W. K.; Ha, H.-J. Aldrichimica Acta 2003, 36, 57. (d) Park, C. S.; Kim, M. S.; Sim, T. B.; Pyun, D. K.; Lee, C. H.; Lee, W. K. $J$. Org. Chem. 2003, 68, 43. (e) Chang, J.-W.; Ha, H.-J.; Park, C. S.; Kim, M. S.; Lee, W. K. Heterocycles 2002, 57, 1143. (f) Lee, K.D.; Suh, J.-M.; Park, J.-H.; Ha, H.-J.; Choi, H. G.; Park, C. S.; Chang, J. W.; Lee, W. K.; Dong, Y.; Yun, H. Tetrahedron 2001, 57, 8267. (g) Park, C. S.; Choi, H. G.; Lee, H.; Lee, W. K.; Ha, H.J. Tetrahedron: Asymmetry 2000, 11, 3283. (h) Bae, J. H.; Shin, S.-H.; Park, C. S.; Lee, W. K. Tetrahedron 1999, 55, 10041. (i) Choi, S.-K.; Lee, J.-S.; Kim, J.-H.; Lee, W. K. J. Org. Chem.
$1997,62,743$

4. It has been reported on $a b$ initio studies of aziridine inversion energy using various methods and basis sets. For recent report of $\mathrm{N}$-inversion energy of aziridines, see: (a) Ebrahini, A.; Deyhimi, F.; Roohi, H. J. Mol. Struct. 2001, 247. (b) Nielsen, I. M. B. J. Phys. Chem. A 1998, 102(18), 3193-3201.

5. Gaussian 98, Revision A.7, Frisch, M. J. et al., Gaussian, Inc., Pittsburgh, PA, 2002

6. (a) Francl, M. M.; Pietro, W. J.; Hehre, W. J.; Binkley, J. S.; Gordon, M. S.; DeFrees, D. J.; Pople, J. A. J. Chem. Phys. 1982, 3654. (b) Becke, A. D. J. Chem. Phys. 1993, 1372. (c) Lee, C.; Yang, W.; Parr, R. G. Phys. Rev. 1988, 785.

7. For examples of the TS energy calculation using DFT methods, see: (a) Ra, C. S.; Park, G. Bull. Korean Chem. Soc. 2004, 25, 1461. (b) Park, G. Bull. Korean Chem. Soc. 2003, 24, 265. (c) Ra, C. S.; Park, G. Tetrahedron Lett. 2003, 44, 1099.

8. (a) Torssell, K. B. G. Nitrile Oxides Organic Nitro Chemistry Series; VCH: New York, 1988. (b) Davis, F. A.; Jenkins, Jr. R. J. Asymmetric Synthesis, vol. 4; Academic Press: New York, 1983.

9. Forni, A.; Moretti, I.; Proxianky, A. V.; Torre, G. J. Chem. Soc. Chem. Commun. 1981, 588.

10. Wu, J.; Hou, X.-L.; Dai, L.-X. J. Org. Chem. 2000, 1344. In this report, it is considered that the ring opening can occur with TMSCN triggered by fluoride in the presence of TBAF for the reaction mechanism.

11. For other examples of ring opening reaction with cyanide ions, see: (a) Farras, J.; Ginesta, X.; Sutton, P. W.; Taltavull, J.; Egelar, F.; Romea, P.; Urpi, F.; Vilarrasa, J. Tetrahedron 2001, 7665. (b) Yadav, J. S.; Reddy, B. V. S.; Parimala, G.; Reddy, V. Synthesis 2002, 2383. (c) Matsubara, S.; Kodama, T.; Utimoto, K. Tetrahedron Lett. 1990, 6379 